\title{
Soft power, global governance of cultural industries and rising powers: the case of China
}

\section{Antonios Vlassis}

To cite this article: Antonios Vlassis (2016) Soft power, global governance of cultural industries and rising powers: the case of China, International Journal of Cultural Policy, 22:4, 481-496, DOI: 10.1080/10286632.2014.1002487

To link to this article: https://doi.org/10.1080/10286632.2014.1002487

\section{Published online: 26 Jan 2015.}

Submit your article to this journal ๔

Џll Article views: 4122

Q View related articles $\asymp$

View Crossmark data \lceil

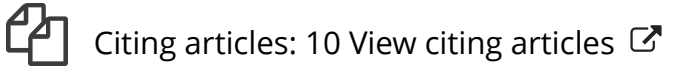




\title{
Soft power, global governance of cultural industries and rising powers: the case of China
}

\author{
Antonios Vlassis* \\ Center for International Relations Studies (CEFIR), Department of Political Science, \\ University of Liège, Fonds national de Recherche Scientifique (FNRS), Liège, Belgium
}

(Received 1 August 2014; accepted 22 December 2014)

\begin{abstract}
This article addresses the importance of cultural industries for the strengthening of the soft power of the rising powers and it seeks to understand how the cultural industries allow rising powers to shape the structures of their international environment. More specifically, studying the cases of People's Republic of China and of the movie industry, my article focuses on the current evolution of the relationship between the Chinese authorities and the film industry, as well as on the development of the domestic film market. I further aim to draw up an inventory of China's role within the global governance of cultural industries. Finally, I aim to highlight the global cultural competition that China faces, emphasizing the practices of the US administration and Hollywood. I argue that even if China is the current centre of gravity within the world economy, it still has a long way to go in order to shape the distribution of resources within the global governance of cultural industries and to play a crucial role in the international battle of cultural symbols.
\end{abstract}

Keywords: China; soft power; global governance; cultural industries; US administration and Hollywood

The cultural industries, oscillated between symbolic and material spheres, raise important issues for many involved actors: economic issues because cultural industries are a key sector in terms of growth and employment for the national economies $^{1}$; political issues, given that cultural industries - seen as vehicles of values and collective representations - are resources of the power of States and of their capacity to shape their international environment; finally, identity issues because cultural expressions - distributed by cultural industries - are usually components of a national, regional or local identity and many actors are increasingly worried on cultural dominance.

In October 2011, the 17th Central Committee of the Chinese Communist Party underlined the need for strengthening the Chinese soft power "with a view to the overall prosperity of cultural undertakings and sound development of cultural industries' and for holding 'fast to the approach of multi-level, extensive international cultural exchanges and continuously improve the international influence of Chinese culture' (Ministry of Culture of the People's Republic of China 2013, p. 3). Since the end of the Cold War, the rise of China on the world stage has been

*Email: avlassis@ulg.ac.be 
one of the most important historical and political phenomena. Its impressive economic growth, its social transformations and its influence on the international affairs force many scholars to question the status of China in the international arena. Is China a rising power that moves on from regional power to global power? Is the desire of the Chinese authorities to challenge the US predominance and to access to the world hegemony? (Johnston 2003, Gipouloux 2006, Cabestan 2010, Shambaugh 2013).

On the one hand, recent studies focus on the foreign cultural action of China and its soft power in order to offer useful insights on these tricky questions (Cheow and Chu 2004, Cho and Jeong 2008, Mingjiang 2009, Barr 2010, Wang 2011, Lai and Lulu 2012, Swielande 2012). In their definition on the soft power, they include various areas such as trade, language, values in the broadest sense, religion and education. However, the cultural industries, and especially film industry, are still an unknown factor for highlighting the role that China can and will play on the global stage. Furthermore, it would point out that the analysis on immaterial resources of power came particularly to dominate the discipline of International Relations (IR) during the 1980s debate on the possible decline of US hegemony (Battistella 2013, p. 239). As such, in 1990, Joseph Nye (1990, 2004) developed the concept of soft power in order to highlight the transformations of the components of the State power in the current international relations. As the prominent American scholar put it, if the United States wishes to be the hegemonic power of the 21th century, it would need to strengthen its soft power, based on intangible resources. ${ }^{2}$ In addition, during the 1980s, Susan Strange elaborated the concept of structural power in order to focus on the tangible and intangible capabilities of the United States to determine the international structures and to provide the leadership on the global scale (Strange 1994). While the two scholars identified multiple variables to understand the transformation of power in the era of globalization, the cultural industries were not adequately addressed in their studies. However, the approach of Susan Strange recently inspired analyses (Scott 2004, Laroche and Bohas 2005, Bohas 2010) on cultural capitalism of the United States and on its main vectors, such as the multinational entertainment corporations (Hollywood).

On the other hand, while there is a lively academic debate in IR about the configuration of actors and of norms within the global governance of a large number of sectors such as environment, energy, labour, or health, relatively little has been said about the international dimension of governance of cultural industries (Singh 2010, Vlassis 2013, 2014a, 2015, Kozymka 2014). Thus, the action and the political influence of China in this context are absent from the IR literature. More specifically, by global governance of cultural industries, I mean a system for organizing the relations of power and of regulation at the world level (Stocker 1998, Cabrera 2011); it is composed of rules, norms and institutions, affecting several aspects of cultural goods and services (creation, production, distribution, exhibition, etc.) and allowing the involved actors to coordinate their practices in a context of disaggregated sovereignty (Slaughter 2004), of polyarchic authority (Avant et al. 2010) and of absence of global government (Rosenau 1997). The global governance of cultural industries is not so much a harmonious and static approach for the today's international cultural relations, but rather a continuous process within which a constant game of bargaining, exchanges and political battles is made (Smouts 1998, Muldoon et al. 2011). 
Collective art, mass art, art of modernity, major industrial art of the contemporary 'screenocracy', 3 the cinema is 'a tool of soft power of nations' (Dagnaud 2011) and the most significant cultural industry in terms of economic profitability and symbolic influence. ${ }^{4}$ Even if the cultural external action of a country seeks various and long term objectives that are very difficult to assess their impact (Gilboa 2008, Morin 2013, p. 41), it is worth addressing not only the role of Chinese film industry for strengthening the Chinese soft power, but also how this cultural industry allows China to build an active status of world power (Santander 2013, p. 524). In this view, I seek in this article to analyse the evolution of the relationship between the Chinese authorities and the film industry, as well as the development of the domestic film market. I further aim to draw up an inventory of China's role within the global governance of cultural industries and its international commitments in this area (General Agreements on Trade in Services-World Trade Organization, 2005 Convention on Diversity of Cultural Expressions-UNESCO). Finally, I aim to address the global cultural competition that China faces, focusing especially on the practices of the US administration and Hollywood.

\section{China: a major cinema power?}

Since the end of the Cold War, the development of the 'electric shadows' industry ${ }^{5}$ has become a priority for the Chinese authorities. The China's State Administration of Radio, Film and Television (SARFT) and the powerful China Film Group manage in a dense and monopolistic way all the components of Chinese movie industry - production, importation, distribution and exhibition - and heavily taxes foreign audiovisual products. The transformation of the Chinese film economy has begun since the 1990s, when the country decided to integrate into the multilateral economic system. In the late of $1980 \mathrm{~s}$, the Chinese film industry went through a profound crisis: significant reduction in the cinema attendance and dramatic decrease in the film production (Zhu and Nakajima 2010, pp. 17-33). Chinese authorities then undertook a slow opening of the film market because of the risk of its collapse and of the pressure from the Clinton administration and Hollywood studios in their ambition to open new film markets (Mingant 2010, pp. 49-50). In 1994, SARFT agreed to give a percentage of revenue for ten foreign films per year (revenue-sharing films) and to keep buying the other movies in a fixed price (flat-fee films) and selecting the imported movies. Despite these barriers to trade, since 1996, the foreign films, and especially Hollywood movies, have captured a 40-50\% stake in the Chinese market (OEA 1998-2013), showing that the Chinese audience is very receptive to Hollywood pictures unlike other Asian countries such as India. ${ }^{6}$ Simultaneously, China has developed a film d'auteur inserted into the international art circuits and receiving many awards in the five major international film festivals (Cannes, Venice, Berlin, San Sebastian and Locarno): without a significant award up until the late 1980s, Chinese films won 19 awards between 1988 and 2014. ${ }^{7}$

Since its WTO accession in 2001, China has been committed to increase the number of imported films: the annual quota of foreign films distributed in revenue-sharing has increased from 10 to 20 (Augros and Kitsopanidou 2009, pp. 226-227). Nevertheless, in 2009, following a complaint lodged by the US administration in $2007,{ }^{8}$ the WTO condemned China for its trade practices within the cultural sector - books, movies, music - and especially for its strict regulatory measures imposed to the US exporters and distributors of many audiovisual 
products. Since then, China has sought to soften its quotas system allowing access to a greater number of foreign revenue-sharing films within its cinema market. ${ }^{9}$ As a result, in February 2012, US and China signed a 'Memorandum of Understanding on WTO Related Problems in the Film Industry' and US Vice President Joe Biden announced that China allowed the importation of 14 more Hollywood movies and increased the percentage of sharing-revenues to the foreign operators from 13 to $25 \%$ (Vlassis 2012). ${ }^{10}$ It is obvious that the relations between China and Hollywood are becoming closer, from a mistrust vis-à-vis movies-symbols of American capitalism and of Westernization to a more intense cooperation and to a slow but constant opening of the Chinese film market to the Hollywood products. In this sense, this partnership has become strategic for the future development not only of the Chinese film industry, but also of Hollywood (Jihong and Kraus 2002).

During the last decade, the priorities of Chinese policy-makers focus on the impressive domestic expansion of the Chinese film industry and on the encouragement of the private investment as a result of the substantial profit margins of the film industry (Zhu 2003, pp. 142-160). The film market in China has been characterized by impressive growth, four or five times higher than the growth of China's GDP. In 2004, total film market revenues represent US\$ 435 million. By contrast, in 2013, China was the world's second largest film market and generated US\$ 3.6 billion in box-office revenue (Table 1). If this trend continues, China will overtake the North-American (US-Canada) market and become the world's first film market by 2020 (UNESCO Institute for Statistics 2013, p. 25). In addition, in 2008, the number of screens was 4.097, while in 2012, this number tripled, reaching 13.118 screens. Finally, in 2012, the Chinese film production reached 745 movies (only 82 movies in 1998).

It's worth mentioning that in September 2013, Wang Jianlin, CEO of the Chinese conglomerate company Wanda - with activities in real estate, tourism and entertainment - announced its plans to build the world's biggest film studio in the east coast of China. It is one of the most massive investments in the film industry history, reaching US\$ 8.2 billion. In parallel, in 2012, Wanda Group agreed to buy AMC Entertainment Holdings Inc. (AMC) for US\$ 2.6 billion, expanding into the US to create the world's biggest cinema owner. The deal marked the largest-ever buyout of a US company by a Chinese firm. The AMC Theatres, founded in 1920, has the second-largest share of the US market, behind Regal Entertainment Group. It reveals that China's objective for boosting its cultural power is not only part of the Chinese authorities, but also of industrial companies: in this regard, Wang Jianlin said that 'in ten years, the Chinese economy will be on way to dethrone US as dominant economic power. But in terms of cultural power, China is still far behind (...) this project is an opportunity to implement a national policy in order to promote cultural power'. ${ }^{11}$

Table 1. Total box-office revenue in five movie markets, 2008-2013 (in US\$ billion).

\begin{tabular}{lccccc}
\hline Countries/Year & 2008 & 2010 & 2011 & 2012 & 2013 \\
\hline China & 0.6 & 1.5 & 2.0 & 2.7 & 3.6 \\
Russia & 0.8 & 1.0 & 1.1 & 1.2 & 1.4 \\
India & 1.8 & 1.3 & 1.4 & 1.5 & 1.5 \\
Japan & 1.8 & 2.5 & 2.2 & 2.4 & 2.4 \\
South Korea & 0.8 & 1.0 & 1.1 & 1.3 & 1.4 \\
\hline
\end{tabular}

Source: MPAA 


\section{China within the international arenas: between modest integration and increasing presence}

Institutional multilateralism occupies a key position in the political strategies of China in order to gain a worthy and outstanding presence within the international cultural affairs. While the normative constraints of the WTO have a clear impact on the structure of the Chinese film industry and they challenge governmental control over cinema industry (as we have noted above), China also seeks to preserve its cultural sovereignty and to play a greater role in the two major issues of the global governance on cultural industries, namely the international recognition of the importance of cultural policies and the international promotion of the cultural development.

China was one of the key-players in the political construction of the Convention on the Diversity of Cultural Expressions (CDCE), adopted by UNESCO in 2005 and dedicated to recognize the specificity of cultural goods and services on the international scale and to legitimize the right of governments to adopt policies within the cultural industries sector (Aylett 2010, Vlassis 2011). A year before the adoption, the Chinese authorities organized the seventh ministerial meeting of the International Network on Cultural Policy (INCP), ${ }^{12}$ held from 14 to 16 October 2004 in Shanghai and attended by Ministers of Culture from 31 countries, by 18 observer countries and by six international organizations. Furthermore, during the negotiations on the CDCE, China supported on the one hand the explicit recognition of the sovereign right of States to implement cultural policies and on the other hand the establishment of an effective Convention vis-à-vis the international regime of the WTO (Vlassis and Richieri-Hanania 2014). In this sense, during the debate on Article 19 of the CDCE draft dealing with the links between the Convention and other international agreements, the Chinese delegation favoured the option A, which provided a non-subordination of the CDCE with trade agreements. China therefore opted for a Convention, which has a legitimate status within the international law, noting in its comments that 'the Convention should become a reference for the WTO and other international bodies. In this regard, all the international regimes would function as a whole (UNESCO 2004, p. 87)'.

China ratified the CDCE in 2007 and it remains one of the most active countries about its implementation. Up till now, its contribution to the International Fund for the Cultural Diversity dedicated to support cultural industries in the developing countries amounts US\$ 310.000, far more than the contribution of India, Germany, Denmark, South Africa, or of Australia, but less than the contribution of Norway (US\$ 1.45 million), France (US\$ 1.42 million), or of Finland (US\$ 538 450).

Note that during the meetings of the panel established by the Dispute Settlement Body (DSB) of the WTO in November 2007 on trade practices of China in the cultural field (as we have seen above), the latter pointed out that its measures are linked to many exceptions (Neuwirth 2010). In its first written submission, China made explicit reference to the CDCE in order to emphasize that cultural goods and services are different from other products and in this view, the WTO members should provide greater leeway to regulate this type of goods and services (WTO 2009, p. 107). In addition, the Chinese delegation noted that the specificity of cultural goods and services is recognized by the CDCE, requesting that the DSB should be aware of the specific nature of cultural goods (WTO 2009, p. 15). 
Instead, the members of the panel argued that the reference to the CDCE does not corroborate the China's position, insofar as the CDCE should not be used as a legal instrument in order to legitimize any violations to the WTO Agreements.

China seeks recently to play an increasing role in international cultural arena to advance its political agenda. In May 2013, in collaboration with UNESCO, it organized the Hangzhou International Congress on 'Culture: key to sustainable development', revealing that the Chinese ambitions are no longer limited to its regional area. 'For the UNESCO, it was better that a rising country organises this Congress. We discussed with the Chinese authorities because they were, in principle, in favour and they wanted to organise a big event'. ${ }^{13}$ This Congress has been the first International Congress on the links between culture and development organized since the Stockholm Conference in 1998. The latter has led to the adoption of UNESCO Universal Declaration on Cultural Diversity in 2001 and then to the CDCE in 2005. In Hangzhou, around 400 experts and involved actors from 80 countries, United Nations agencies and 20 national and international non-governmental organizations emphasized the contribution of culture (cultural industries, material and immaterial heritage) within the policies for the sustainable development. As such, Hangzhou Declaration has marked an important step in the advocacy of UNESCO and of China for the recognition of culture in development programs and the inclusion of culture in the post-2015 United Nations Development Agenda. Although China does not have equal resources with United States, its strategy within UNESCO came to fill the economic and institutional gap created by the putting on hold of the US contribution to UNESCO, following the majority vote on making Palestine a full Member of the organization in $2011 .^{14}$ It's worth noting that in June 2012, in collaboration with the Group of 77, China organized a Round Table entitled 'What Future and What Challenges for UNESCO?' The organizers have stressed that 'today, UNESCO lives a serious moral crisis, whose financial difficulties are mere symptoms of the growing decline of our Organization. The UNESCO of the twenty-first century needs to be rebuilt'. ${ }^{\text {. }}$

\section{China vis-à-vis the global cultural competition}

However, China is not still regarded as a global, or even regional cultural power, with capacities to change profoundly the balance of power within the global audiovisual economy. The trade balance of the US audiovisual industry has long been positive, although the United States has traditionally recorded a trade deficit. Since 1980s, Hollywood has been one of America's largest net exporting industries and in 2012, the surplus in audiovisual sector reached US\$ 13.5 billion (Table 2), more than the trade surplus in telecommunication, management/consulting, legal services, medical sector or computer services (United States International Trade Commission 2014).

Table 2. Audiovisual services: US cross-border trade in audiovisual services resulted in a US trade surplus each year during 2008 (in US\$ billion).

\begin{tabular}{lrrrrr}
\hline & 2008 & 2009 & 2010 & 2011 & 2012 \\
\hline Exports & 13.2 & 13.7 & 13.6 & 14.5 & 16.2 \\
Imports & 1.7 & 1.9 & 1.6 & 2.0 & 2.6 \\
Trade balance & 11.4 & 11.8 & 12.0 & 12.5 & 13.5 \\
\hline
\end{tabular}

Source: MPAA, United States International Trade Commission. 
Inspired by the world system theory of the French historian Fernand Braudel, Charles-Albert Michalet pointed out that since 1980s, Hollywood has developed the strategy of cinema-world based on three mechanisms: a world movie, both movie event and global film; a global approach on the market; horizontal cooperation among companies centred on entertainment activities. 'The cinema-world reflects the economic forces that showed up the global capitalism, namely an economic system that can only be operating in a global dimension' (Michalet 1987, p. 112). Enjoying main technological developments, the Hollywood film also remains a key product for the main media platforms (DVD, TV and Internet). In addition, the US audiovisual services exports reached US\$ 13.5 billion in 2010, whereas those from China totalled only US\$ 123 million (WTO 2012). The most remarkable point is that while many US industries have to face trade competition from their international counterparts, Hollywood has no real international competitor. Therefore, even if the financial and regulatory measures for the film industry seek to maintain and to promote a national cinematography such as in France, in South Korea, or even in China (OEA 1998-2013), ${ }^{16}$ they fail to challenge the dominance of Hollywood in terms of attraction capacity and worldwide distribution (Crane 2013, Vlassis 2015).

It's revealing that during the period 2008-2013, the 15 highest film successes, distributed by Hollywood studios, represent about a third of annual worldwide cinema revenues: in 2013, they accumulate about $32 \%$ of revenue in the global film market, $34 \%$ in $2012,30.5 \%$ in 2010 and $30 \%$ in 2008 . An additional important point is that on the one hand in 2013, the 15 highest movie successes, distributed by Hollywood, recorded more than half of their revenues in the cinema markets outside the United States and Canada and on the other hand, during the period 2007-2014, 24 Hollywood blockbusters recorded more than $74 \%$ of their total box office revenues in the 'international' markets (Table 3). As we can see, all these statistics reveal the expertise and the financing and marketing capabilities of Hollywood in terms of worldwide film distribution. Despite their competition with each other, the Hollywood studios are usually connected by a common film language and a strong strategic interdependence (Trumbour 2008, Augros and Kitsopanidou 2009).

Most interesting perhaps is that only 18 non-Hollywood movie productions are part of the list of the all-time worldwide box-office grosses including 586 films: European blockbusters: Taken 1 and 2, Lucy, Resident Evil, The Fifth Element; European comedy movies: Four weddings and a funeral, Intouchables, Bean, The Full Monty, Bienvenue chez les ch'tis; Oscar winning movies: The King's Speech, Slumdog Millionaire, La Vittà è bella; Japanese animation movies: Spirited away, Howl's Moving Castle and Ponyo, as well as the Chinese production Crouching Tiger Hidden Dragon (Tables 4 and 5). Among these movies, only seven are nonAnglophone movies, 13 are British, French, or German productions and only one is a Chinese production. ${ }^{17}$

To this should be added that over the last twenty-five years and with certain minor movie exceptions, such as Lucy, Taken I and II, Slumdog Millionaire, The King's Speech, Crouching Tiger Hidden Dragon - that recorded important box-office revenue in the US market (over US\$ 100 million) - the market share of non-US movie productions is extremely low, going from 2 to $9 \%$. In this regard, the 'cinema-world' contributes to increase the imbalance within the global audiovisual economy and to establish the Hollywood dominance in two directions: on the one hand, it is used for limiting the access of foreign movies - which do 
Table 3. Hollywood blockbusters and the percentage of their total box-office revenues within the 'international markets' (outside the US and Canada), 2007-2014.

\begin{tabular}{lc}
\hline & $\begin{array}{c}\text { \% of its global } \\
\text { revenues within the } \\
\text { 'international markets' }\end{array}$ \\
Film & 82.0 \\
\hline Gulliver's Travel (2010) & 81.6 \\
Ice Age: Continental Drift (2012) & 81.2 \\
The Golden Compass (2007) & 79.6 \\
The Smurfs 2 (2013) & 79.5 \\
Life of Pi (2012) & 79.3 \\
The Adventures of Tintin (2011) & 78.4 \\
Battleship (2012) & 78.4 \\
2012 (2009) & 77.9 \\
A Good Day to Die Hard (2013) & 77.8 \\
Ice Age: Dawn of the Dinosaurs (2009) & 77.4 \\
Transformers: Age of Extinction (2014) & 76.9 \\
Pirates of the Caribbean: On Stranger Tides (2011) & 76.4 \\
Mamma Mia (2008) & 75.9 \\
RoboCop (2014) & 75.7 \\
The Tourist (2010) & 75.7 \\
American Reunion (2012) & 75.4 \\
Hansel and Gretel: Witch Hunters (2013) & 75.2 \\
Pacific Rim (2013) & 75.2 \\
After Earth (2013) & 75.2 \\
Kung Fu Panda 2 (2011) & 74.9 \\
Chronicles of Narnia: The Voyage of the Dawn Treader (2010) & 74.7 \\
The Strumfs (2011) & 74.4 \\
The Mummy: Tomb of the Dragon Emperor (2008) & 74.3 \\
John Carter (2012) &
\end{tabular}

Source: Mojo.

not enjoy the necessary financial and marketing resources such as Hollywood studios - to the US market based on an exclusive deregulation; on the other hand, following the same logic, it grants the advantage to Hollywood movies within the 'international markets', serving to a progressive coordination of national markets and to a convergence of the audience's preferences (Scott 2004, Laroche and Bohas 2005, Miller et al. 2005, Vlassis 2015).

Moreover, since the multilateral negotiations on the GATS (General Agreement on Trade in Services-WTO) and the debate on exception culturelle (cultural exception), the opening of film markets and the elimination of regulatory and financial measures in the audiovisual sector also has been a major priority of the US trade diplomacy. 'The US motivation was obvious: replacing national societies of culture with a global society of alleged efficiency' (Miller and Yùdice 2002, p. 174).

In March 2013, 34 WTO members, including China, have agreed to make commitments in the audiovisual services sector. Note that 18 governments of 134 founding members of the WTO took commitments in 1995, whereas during the period from 1996 to 2013, 16 governments of the 25 new WTO members ${ }^{18}$ agreed to be subject to certain restrictions in the audiovisual sector. This reveals not only the US pressures in favour of the liberalization of the audiovisual sector, but also the fact that a government negotiates its accession to the WTO without being able to build coalitions. 'All these countries need the ticket of accession, and this ticket is very high here'. ${ }^{19}$ As such, 'in the WTO, on the one hand, the position of US 
Table 4. All-time worldwide box-office grosses, Top-18 Hollywood productions.

Film

Worldwide revenues

Avatar (2009)

(in US\$ million)

Titanic (1997)

The Avengers (2012)

2788.0

2186.8

Harry Potter and the Deathly Hallows Part 2 (2011)

1518.6

1341.5

Frozen (2013)

Iron Man 3 (2013)

1267.8

1215.4

Transformers: Dark of the Moon (2011)

1123.8

The Lord of the Rings: the Return of the King (2003)

1119.9

1108.6

1084.4

Transformers: Age of Extinction (2014)

1084.4

1066.2

1063.2

1045.7

1029.2

1027.0

1025.5

Star Wars: Episode I-The Phantom Menace (1999)

Alice in Wonderland (2010)

The Hobbit: An Unexpected Journey (2012)

1017.0

Source: Mojo.

Table 5. All-time worldwide box-office grosses, Top-18 non-Hollywood productions.

\begin{tabular}{lc}
\hline Film & Worldwide revenues (in US\$ million) \\
\hline Lucy (2014) & 458.8 \\
Intouchables (2011) & 426.5 \\
The King's Speech (2010) & 414.9 \\
Slumdog Millionaire (2008) & 377.9 \\
Taken 2 (2012) & 376.1 \\
Resident Evil: Afterlife (2010) & 296.2 \\
Spirited Away (2001) & 274.9 \\
The Fifth Element (1997) & 263.9 \\
The Full Monty (1997) & 257.9 \\
Bean (1997) & 251.2 \\
Four weddings and a Funeral (1994) & 245.7 \\
Bienvenue chez les Ch'tis (2008) & 245.1 \\
Resident Evil: Retribution (2012) & 240.1 \\
Howl's Moving Castle (2004) & 235.1 \\
La Vittà è bella (1998) & 229.2 \\
Taken (2009) & 226.8 \\
Crouching Tiger, Hidden Dragon (2000) & 213.5 \\
Ponyo (2009) & 201.8 \\
\hline
\end{tabular}

Source: Mojo.

administration (regarding the audiovisual services) is positive and offensive, while the position of European Union is negative and defensive (...) when you negotiate your accession within the WTO, you should please everyone' and especially the most influential and powerful countries. ${ }^{20}$

Following the exhaustion of the WTO negotiation model (Petiteville 2013), the US administration recently promotes a multilateralism à la carte, ${ }^{21}$ that offers more 
autonomy and flexibility to negotiators and it could go much further in respect of content and trade disciplines (Deblock 2010, Gagné 2011). In the context of recent trade negotiations - such as the Trans-Pacific Partnership negotiations, including 12 countries such as US, Canada, Japan, Mexico and Australia, and the negotiations on the TISA, which currently includes 23 economies, ${ }^{22}$ being part of the WTO informal group 'Really good friends of Services' - one of the major goals of the Obama Administration and of the MPAA is the inclusion of the digital cultural services such as video on demand or catch-up television within the agenda of negotiations. All this means that governments are supposed to maintain their regulatory and financial capabilities in the sector of conventional cultural services (film theatres, video-DVD, conventional TV), but they would be deprived of their ability to implement new policy mechanisms for the digital services, which represent the future of the cultural sector (Vlassis and Richieri-Hanania 2014, Vlassis 2014b). ${ }^{23}$ It's worth noting that China wants to join the TISA negotiations in order to develop a more dynamic and efficient services domestic sector and to not isolate itself from the recent evolutions in international trade. The US administration, however, is very reluctant, requiring from China to make further domestic reforms within the services sector, including the cultural services. ${ }^{24}$

Likewise, another stumbling block between China and US administration remains the piracy and counterfeiting of cultural products. ${ }^{25}$ Despite the recent reforms (Dimitrov 2009), for a 10th consecutive year, China is still part of the Priority Watch List of the Special Report 301, prepared by the USTR (United States Trade Representative) in collaboration with several private sector coalitions, such as the MPAA or International Intellectual Property Alliance. ${ }^{26}$

Finally, at the regional level, China is also faced with many Asian countries with substantial cultural and symbolic resources. South Korea has a very dynamic film sector and a thriving music industry (K-pop) and the country has also made important investments in new technologies (Courmont and Kim 2013). Manga comics, animation movies, such as Princess Mononoke (1997), Spirited away (2001), Howl's Moving Castle (2004) and Ponyo (2009), and karaoke - Japanese form of entertainment - are global symbols related to the Japanese culture. In addition, India remains the world's largest producer of films in the world and movie exporter in Asia, Africa and the Middle East.

\section{Conclusion}

This article has offered a first investigation into the importance of the cultural industries for the rising powers and the role of the latters within the global governance of culture. The preceding overview reveals two main points: on the one hand, China, absorbed into the spectacular domestic transformation of its film industry, has a minor impact within the world circulation of audiovisual goods and services; on the other hand, China complies with the institutional architecture of the global governance of cultural industries and it prefers the role of 'follower' (Le Prestre 2005, p. 99), recognizing a certain connivance with the European Union and Canada about the importance of cultural policies at the international level and avoiding confrontation with the US administration. Hence, even if the Chinese foreign action about cultural industries is increasingly dynamic, its political influence and capacity to construct and impose new principles and norms are so far very restricted. 
Further, understanding Hollywood and US administration's strategies is essential for assessing whether China could play a crucial role within the global governance of cultural industries. Hollywood, exerting technical and ideological influence, still has unequalled expertise, global distribution strategies, as well as unique capacity of innovation and funding. To this can be added that the US foreign trade policy is a substantial diplomatic tool in order to promote the conquest of new audiovisual markets, including China, and to strengthen the comparative advantage of the US in the new information and communication technologies (Vlassis 2015).

Laurent Creton has pointed out that in many countries, Hollywood is not currently regarded as a national cinematography but as the cinema (Creton 1997, p. 106); it must be kept in mind that Hollywood productions are still the only global cultural symbols and represent the United States as the core of globalization and as a new globalizing civilization (Kurth 2010, p. 64). Ultimately, the history of international relations reveals that the power of countries seeking a greater role within the international affairs is not only based on military and economic resources, but also on symbols that capture the collective imaginaire. While China is the current centre of gravity within the world economy, it still has a long way to go in order to play an influential role in the international battle of cultural symbols and to shape the distribution of norms and resources within the global governance of cultural industries.

\section{Acknowledgements}

I am grateful to Sebastian Santander and Sophie Wintgens, as well as to the anonymous reviewers for their valuable comments on previous versions. An earlier version of this article was presented at the 8th International Conference on Cultural Policy Research, Hildesheim, 11 September 2014, at the panel "The 2005 Convention in Practice-Catch me if you can" organized by the U40 Network "Cultural Diversity 2030". This article was carried out with support from the Fonds national de Recherche Scientifique (Belgium), as well as the David Constant Fund, managed by the King Baudouin Foundation.

\section{Notes}

1. According to the United Nations Creative Economy Report, world trade of cultural goods and services totalled a record of US\$ 624 billion in 2011 and more than doubled from 2002 to 2011 (UNESCO-United Nations Development Program 2013).

2. About a critical analysis on the concept of soft power, see (Bohas 2006, Chavagneux 2010, pp. 26-29).

3. The ubiquity and the omnipresence of screen in our daily lives (écranocratie) (Lipovetsky and Serroy 2007).

4. According to the UNESCO Institute for Statistics, feature films are one of the most popular cultural expressions worldwide, with an audience of approximately 7.5 billion people per year.

5. The Chinese term for movies.

6. When the Hollywood movies box office threatens to exceed the revenues of the Chinese movies, the Chinese authorities decide to establish a 'total black-out'; it means that all the foreign films are banned from the movie theatres. These periods are called 'periods for the domestic movie protection' (Martel 2011, p. 256).

7. I refer to the highest awards of the international festivals, such as Golden Palm (Cannes), Golden Lion (Venice), Golden Bear (Berlin), Golden Leopard (Locarno), Golden Shell (San Sebastian) and the Grand Prix of the festival juries. More specifically, from 1988 to 2014, Chinese films won three major awards at the Cannes Festival, eight awards at the Berlin Festival, three at the Venice Festival, four at the Locarno Festival, and one at San Sebastian Film Festival (see also Balme 2013). 
8. In 2006, Washington initiated the current US strategy of using the judicial forum of the WTO to manage bilateral trade frictions with China (Bown 2009).

9. Instead, China still emphasizes a strict censorship that imposes substantial barriers for protecting not only the audience from the foreign political and cultural influence, but also the Chinese market. Several elements are thus supposed to be subject to censorship: distorting Chinese civilization and history; disparaging the image of the people's army, public security organ or judiciary; showing obscene and vulgar content; showing contents of murder, violence, terror; advertising religious extremism; showing excessive drinking, smoking and other bad habits, etc. There are no official statistics for the total number of censored movies per year, but it's worth mentioning that in 2012, during the fifth edition of the European film Festival organized by the European Union in China, 15 out of 27 movies were rejected by the SARFT.

10. Other foreign movies, whose the number is annually changing, are bought by China Film Group with fixed-price contracts (flat-fee films). To these quotas a condition about the movie exhibition is added: the relation between Chinese and foreign movies should not be less than $2 / 3$ of screen time for Chinese movies and $1 / 3$ for foreign movies, regardless the type of remuneration (revenue-sharing or flat fee films). Note that since 1999, the quotas have not applied to co-productions; the number of the latters has been increased from 10 in 2001 to 67 in 2012. On the one hand, the co-productions have become a major tool for the Chinese authorities in order to attract investors and to control the content of the movies. On the other hand, they are a significant instrument for foreign producers and distributors to penetrate the Chinese film market, while also complying with the Chinese censorship policy. For instance, since 2011, in collaboration with the Motion Pictures Association of America (MPAA), the SARFT has organized the 'China Co-Production Film Screenings' in Los Angeles.

11. 'China to build world's most expensive film studio', The Guardian, 23 September 2013.

12. Instigated by Canada in June 1998, the International Network on Cultural Policy (INCP) was an informal, international venue where national ministers responsible for culture explored and exchanged on new and emerging policy and developed strategies to promote cultural diversity. The last meeting of the INCP took place in 2007.

13. Interview with a high-ranking official at the UNESCO, 15 May 2014.

14. On 8 November 2013, the US lost its voting rights within UNESCO. The US administration has not contributed to the UNESCO budget in 2011, 2012 and 2013, following the US legislation adopted in the early 1990s. The latter prohibits any funding for a UN agency that admits groups and organizations without all the internationally recognized characteristics of a State. The UNESCO budget rises to US\$ 507 million in 2014, which means a reduction of US\$ 146 million compared to the initial budget.

15. Group of 77 and China, UNESCO-Paris, Available from: http://www.g77.org/paris/doc uments/TEXT\%20English.pdf.

16. Peter S. Grant and Chris Wood distinguish between positive and negative quotas. Positive quotas aim to 'give to the audiences a large choice of audiovisual products, without prohibiting access to a specific kind of product'. The European Union 'Television without Frontiers' Directive is thus an example of positive quota in the sense that its provisions are inclusive and non-exclusive. Quite the contrary, negative quotas seek to 'prevent access to a diverse cultural expression'. As the authors point out, 'Chinese regulations restricting the import of foreign films to 20 is an example of negative quota. It excludes foreign cultural products much more than is necessary to make room for local cultural expression' (Grant and Wood 2004, pp. 288-289). For a diametrically opposite approach, see the article of Shalia Sakona (2013), who compares the Chinese regulations with the EU Television without Frontiers Directive. She argues that 'foreign barriers to audiovisual trade, like those posed by Television Without Frontiers and China's current film distribution framework, threaten the continued success of Hollywood (...) the United States should take a uniformly aggressive stance against foreign barriers to audiovisual trade to protect Hollywood's interests abroad'.

17. Source: Mojo, Available from: http://boxofficemojo.com/alltime/world/.

18. Armenia, Cape Verde, China, Georgia, Jordan, Kyrgyzstan, Oman, Panama, Russia, Samoa, Saudi Arabia, Taiwan, Tajikistan, Tonga, Gambia, Vanuatu. 
19. Interview with a high-ranking official at the WTO, 11 April 2014.

20. Interview with a high-ranking official at the WTO, 9 April 2014.

21. It is necessary to distinguish the multilateralism à la carte from other closed concepts, like regionalism, bilateralism, or plurilateralism. Unlike regionalism, the multilateralism à la carte, such as the recent negotiations on the Trade in Services Agreement (TISA) or the Anti-Counterfeiting Trade Agreement, is not limited to a geographical area and it is not based on the geographical proximity. Moreover, it is not necessarily result in the establishment of institutional mechanisms, such as the case of Mercosur (institutional multilateralism). Unlike the bilateralism, it includes more than two participants. Finally, I prefer the concept of multilateralism à la carte to plurilateralism, because it makes more explicit the eclectic character of the US strategy.

22. Australia, Canada, Chile, Colombia, Costa-Rica, European Union, Hong-Kong, Island, Israel, Japan, Mexico, Liechtenstein, New Zealand, Norway, Pakistan, Panama, Paraguay, Peru, South Korea, Switzerland, Taiwan, Turkey.

23. Mid-June 2014, the Coalition of Services Industries (Team TiSA) was established in order to represent the interests of the American service economy. The Coalition seeks to exert political pressure on governments and to influence the agenda of current trade negotiations on the TISA. Among the members, it's worth mentioning Google, MPAA, The Walt Disney Company, Microsoft, twenty-first Century Fox, HP, Intel. 'US Industry Groups Launch "Team Tisa" To Promote Plurilateral Services Talks', Inside US Trade, 19 June 2014.

24. Interview with a high-ranking official at the WTO, 9 April 2014.

25. In April 2007, the United States initiated a complementary dispute within the WTO over the Beijing's failure to enforce American intellectual property rights protection. In January 2009, the WTO issued the report of a panel that had examined the United States' complaint. The Panel recommended that China should bring the Copyright Law and the Customs measures into conformity with its obligations under the TRIPS agreement (Trade-Related Aspects of Intellectual Property Rights). Available from: http:// www.wto.org/english/tratop_e/dispu_e/cases_e/ds362_e.htm.

26. The Special 301 Report is prepared annually by the Office of the United States Trade (USTR) under Section 301. The report identifies trade barriers to US companies and products due to the intellectual property laws. It seeks to identify countries which do not provide 'adequate and effective' protection on intellectual property rights and 'fair and equitable market access to United States persons that rely upon intellectual property rights'. Available from: http://www.ustr.gov/about-us/press-office/press-releases/ 2014/April/USTR-Releases-Annual-Special-301-Report-on-Intellectual-Property-Rights.

\section{References}

Augros, J. and Kitsopanidou, K., 2009. L'économie du cinéma américain: histoire d'une industrie culturelle et de ses stratégies [The economy of the US cinema: history of a cultural industry and its strategies]. Paris: Armand Colin, 286 p.

Avant, D.D., Finnemore, M. and Sell, S.K., 2010. Who governs the globe?. New York: Cambridge University Press, $456 \mathrm{p}$.

Aylett, H., 2010. An international instrument for international cultural policy: The challenge of UNESCO's Convention on the Protection and Promotion of the Diversity of Cultural Expressions 2005. International journal of cultural studies, 13, 355-373.

Balme, S., 2013. L'impuissance paradoxale du «soft power» de la Chine post-Mao [The paradoxical powerless of the post-Mao China's "Soft Power"]. CERISCOPE Puissance [published online]. Available from: http://ceriscope.sciences-po.fr/puissance/content/ part4/1-impuissance-du-soft-power-chinois?page=show [Accessed 7 July 2014].

Barr, M., 2010. Mythe et réalité du soft power de la Chine [Myth and reality of the China's soft power]. Études internationales, 41 (4), 503-520.

Battistella, D., 2013. Puissance, vers une approche synthétique? [Power, towards a synthetic approach?] In: D. Battistella, ed. Relations internationales, Bilan et perspectives [International relations, review and prospects]. Paris: Ellipses, 237-260.

Bohas, A., 2006. The Paradox of Anti-Americanism: reflection on the shallow concept of soft power. Global society, 20 (4), 395-414. 
Bohas, A., 2010. Disney, un capitalisme mondial du rêve [Disney, a global capitalism of the dream]. Paris: L'Harmattan, $250 \mathrm{p}$.

Bown, C.B., 2009. US-China trade conflicts and the future of the WTO. The Fletcher forum of world affairs, 33 (1), 27-48.

Cabestan, J.-P., 2010. La politique internationale de la Chine: entre intégration et volonté de puissance [The international policy of China: between integration and will of power]. Paris: Presses de Sciences Po, 460.

Cabrera, L., ed. 2011. Global governance, global government: institutional visions for an evolving world. Albany, NY: Sunny Press, 327 p.

Chavagneux, C., 2010. Économie politique internationale (2004). 2e éd. Paris: La Découverte, $128 \mathrm{p}$.

Cheow, E. and Chu, T., 2004. La Chine, soft power régional [China, regional soft power]. Politique étrangère, 69 (4), 807-819.

Cho, Y.N. and Jeong, J.H., 2008. China's soft power: discussions, resources, and prospects. Asian survey, 48 (3), 453-472.

Courmont, B. and Kim, E., 2013. Le soft power coréen à l'assaut du monde [The Korean soft power attacking the world]. Monde chinois, 34, 30-41.

Crane, D., 2013. Cultural globalization and the dominance of the American film industry: cultural policies, national film industries, and transnational film. International journal of cultural policy, September, 365-382 (published online). Available from: http://www.tand fonline.com/doi/full/10.1080/10286632.2013.832233\#.Ux9All7yuCc [Accessed 18 June 2014].

Creton, L., 1997. Cinéma et marché [Cinema and market]. Paris: Armand Colin, 256 p.

Dagnaud, M., 2011. Le cinéma, instrument du soft power des nations [Cinema, an instrument of the soft power of nations]. Revue française de Géoéconomie, 58, 21-30.

Deblock, C., 2010. Le bilatéralisme commercial des Etats-Unis [The US trade bilateralism]. In: B. Remiche and H. Ruiz-Fabri, eds. Le commerce international entre bi et multilatéralisme [The international trade between bi and multilateralism]. Bruxelles: Larcier, $115-173$.

Dimitrov, M., 2009. Piracy and the state: the politics of intellectual property rights in China. New York: Cambridge University Press, 207 p.

Gagné, G., 2011. Free trade and cultural policies: evidence from three U.S. agreements. Journal of world trade, 45 (6), 1267-1284.

Gilboa, E., 2008. Searching for a theory of public diplomacy. The annals of the American academy of political and social science, 616 (1), 55-77.

Gipouloux, F., 2006. La Chine du 2lème siècle: une nouvelle superpuissance? [China in the 21th century: a new superpower?]. Paris: Armand Colin, 241 p.

Grant, P. and Wood, C., 2004. Le marché des étoiles: Culture populaire et mondialisation [The market of the stars: pop culture and globalization]. Montréal: Boréal editions, 596 p.

Jihong, W. and Kraus, R., 2002. Hollywood and China as adversaries and allies. Pacific affairs, 75 (3), 419-434.

Johnston, A.I., 2003. Is China a status-quo power? International security, 27 (4), 5-56.

Kozymka, I., 2014. The diplomacy of culture: the role of UNESCO in sustaining cultural diversity. New York: Palgrave Macmillan, 256.

Kurth, J., 2010. The United States as a civilizational leader. In: P. Katzenstein, ed. Civilization in world politics. New York: Routledge, 41-66.

Lai, H. and Lulu, Y., eds., 2012. China's soft power and international relations. New York, NY: Routledge, $216 \mathrm{p}$.

Laroche, J. and Bohas, A., 2005. Canal+ et les majors américaines, une vision désenchantée du cinéma-monde [Canal+ and Hollywood, a disenchanted picture of the cinema-world]. Paris: Pepper, 198 p.

Le Prestre, P., 2005. Protection de l'environnement et relations internationales: les défis de l'écopolitique mondiale [Protection of the environment and international relations: the challenges of the global ecopolicy]. Paris: Armand Colin, $479 \mathrm{p}$.

Lipovetsky, G. and Serroy, J., 2007. L'écran global: culture-médias et cinéma à l'âge hypermoderne [The global screen: culture-medias and cinema in the hyper-modern age]. Paris: Éditions de Seuil, 361 p. 
Martel, F., 2011. Mainstream, enquête sur la guerre globale de la culture et des médias [Mainstream, investigation on the global war on culture and medias]. Paris: Flammarion, $560 \mathrm{p}$.

Michalet, C.-A., 1987. Le drôle de drame du cinéma mondial [The tragic comedy of the global cinema]. Paris: La Découverte, 214 p.

Miller, T. and Yùdice, G., 2002. Cultural policy. London: Sage, 256 p.

Miller, T., et al., 2005. Global Hollywood 2. London: British Film Institute, 442.

Mingant, N., 2010. Hollywood à la conquête du monde. Marchés, stratégies, influences [Hollywood conquering the world: markets, strategies and influences]. Paris: CNRS ed., $320 \mathrm{p}$.

Mingjiang, L., ed., 2009. Soft power, China's emerging strategy in international politics. Plymouth: Lexington Books, 275 p.

Ministry of Culture of the People's Republic of China, 2013. Quadrennial periodic report on measures to protect and promote the diversity of cultural expressions. UNESCO. Available from: https://fr.unesco.org/creativity/sites/creativity/files/periodic_report/ China_Report_OwnFormat_EN_2013_0.pdf [Accessed 2 December 2014].

Morin, J.-F., 2013. La politique étrangère. Théories, méthodes et références [Foreign policy: theories, methods and references]. Paris: Armand Colin, 320 p.

Muldoon, J.P., Aviel, J.F. and Reitano, R., eds., 2011. The new dynamics of multilateralism: diplomacy, international organizations and global governance. Boudler: Westview Press, $369 \mathrm{p}$.

Neuwirth, R.J., 2010. The "Culture and Trade" Debate Continues. The UNESCO Convention in Light of the WTO Reports in China-Publications and Audiovisual Products. Between Amnesia or Déjà Vu? Journal of world trade, 44 (6), 1333-1356.

Nye, J.S., 1990. Bounding to lead: the changing nature of American power. New York: Basic Books, 307 p.

Nye, J.S., 2004. Soft power, the means to success in world politics. New York: Public Affairs, $191 \mathrm{p}$.

OEA-Observatoire européen de l'audiovisuel, 1998-2013. FOCUS, Tendances du marché mondial du film [World film market trends]. Strasbourg: OEA.

Petiteville, F., 2013. Les négociations multilatérales à l'OMC, l'épuisement d'un modèle [Multilateral negotiations in the WTO, the exhaustion of a model]. In: F. Petiteville and P.-F. Delphine, eds. Négociations internationales [International negotiations]. Paris: Presses de Sciences Po, 345-371.

Rosenau, J., 1997. Along the domestic-foreign frontier, exploring governance in a turbulent world. Cambridge: Cambridge University Press, $467 \mathrm{p}$.

Sakona, S., 2013. Frankly, my dear America, we don't give a damn: comparing Chinese and European trade barriers to American audiovisual works and the American response. Boston college law review, 54 (3), 1385-1414.

Santander, S., 2013. Les puissances émergentes, portée et limites d'un phénomène international [The rising powers, scope and limits of an international phenomena]. In: D. Battistella, ed. Relations internationales, Bilan et perspectives [International relations, review and prospects]. Paris: Ellipses, 523-544.

Scott, A.J., 2004. Hollywood and the world: the geography of motion-picture distribution and marketing. Review of international political economy, 11 (1), 33-61.

Shambaugh, D., 2013. China goes global. The partial power. New York, NY: Oxford University Press, 409.

Singh, J.P., 2010. China goes global. The partial power. New York: Palgrave Macmillan, 243.

Slaughter, A.-M., 2004. A new world order: government networks and the Disaggregated State. Princeton: Princeton University Press, 368 p.

Smouts, M.-C., 1998. La coopération internationale: de la coexistence à la gouvernance mondiale [International cooperation: from coexistence to global governance]. In: M.-C. Smouts, ed. Les nouvelles relations internationales: Pratiques et théories [The new international relations: practices and theories]. Paris: Presses de Sciences Po, 135-160.

Stocker, G., 1998. Cinq propositions pour une théorie de la gouvernance. Revue internationale des sciences sociales, 155 (March), 19-29. 
Strange, S., 1994. States and markets: an introduction to international political economy (1988). 2e ed. London: Frances Pinter, 263 p.

Swielande, T.S., 2012. Soft power, le nouveau cheval de bataille chinois? [Soft power, the new boost of China] In: T.S. Swielande and T. De Wilde d'Estmael, eds., La Chine sur la scène internationale [China on the international stage]. Bruxelles: Peter Lang, 55-70.

Trumbour, J., 2008. Hollywood and the world: export or die. In: P. Macdonald and J. Wasko, eds. The contemporary film industry. Oxford: Blackwell Publishing, 209-219.

UNESCO, 2004. Avant-projet de Convention sur la protection de la diversité des contenus culturels et des expressions artistiques: Partie II: Commentaires spécifiques des Étatsmembres. CLT/CPD/2004/CONF.607/1, December.

UNESCO Institute for Statistics, 2013. Emerging markets and the digitalization of the film industry: an analysis of the 2012 UIS international survey of feature film statistics. Information Paper, 14, August.

UNESCO-United Nations Development Program, 2013. Creative economy report 2013. New York: UNESCO/UNDP.

United States International Trade Commission, 2014. Recent trends in US services trade, 2014 annual report. Washington, DC, Publication Number: 4463. Available from: http:// www.usitc.gov/publications/332/pub4463.pdf [Accessed 20 July 2014].

Vlassis, A., 2011. La mise en œuvre de la Convention sur la diversité des expressions culturelles: portée et enjeux de l'interface "commerce-culture" [The implementation of the Convention on the diversity of cultural expressions: scope and stakes of the interface "trade-culture"]. Études internationales, 42 (4), 493-510.

Vlassis, A., 2012. Ouverture des marchés cinématographiques et remise en cause de la diversité culturelle [Opening of movie markets and questionings on cultural diversity]. Revue française de Géoéconomie, 62, 97-108.

Vlassis, A., 2013. L'UNESCO face à l'enjeu 'commerce-culture', Quelle action politique pour une organisation internationale? [The UNESCO vis-à-vis the stake "trade-culture": which political action for an international organization?] Politique et sociétés, 32 (3), 81-101.

Vlassis, A., 2014a. Gouvernance mondiale et culture: De l'exception à la diversité [Global governance and culture: from exception to diversity]. Liège: Presses Universitaires de Liège, $325 \mathrm{p}$.

Vlassis, A., 2014b. Le numérique, nouvelle frontière de la gouvernance mondiale des industries culturelles? [The digital issue, new frontier of the global governance of the cultural industries?] Revue de la Faculté de droit de l'Université de Liège (Larcier), 59 (2), 283-300.

Vlassis, A., 2015. Les industries culturelles, vecteurs de la puissance de l'Inde? [The cultural industries, vector of the Indian power?] Etudes internationales (forthcoming).

Vlassis, A. and Richieri-Hanania, L., 2014. Effects of the CDCE on trade negotiations. In: L. Richieri-Hanania, ed. Cultural diversity in international law: the effectiveness of the UNESCO Convention on the Protection and Promotion of the Diversity of Cultural Expressions. New York: Routledge, 25-39.

Wang, J., ed., 2011. Soft power in China: public diplomacy through communication. New York, NY: Palgrave Macmillan, $208 \mathrm{p}$.

WTO, 2009. China-measures affecting trading rights and distribution services for certain publications and audiovisual entertainment products, report of the panel. WT/DS363/R, 12 August.

WTO, 2012. International Trade Statistics 2012-trade in commercial services. Available from: http://www.wto.org/english/res e/statis_e/its2012 e/its2012 e.pdf [Accessed 10 July 2014].

Zhu, T., 2003. Building institutional capacity for China's new economic opening. In: L. Weiss, ed., States in the global economy: bringing domestic institutions back in. Cambridge: Cambridge University Press, 142-160.

Zhu, Y. and Nakajima, S., 2010. The evolution of Chinese Film as an industry. In: Y. Zhu and S. Rosen, eds. Art, politics and commerce in Chinese Cinema. Hong Kong: Hong Kong University Press, 17-33. 